\title{
Abelson Tyrosine-Protein Kinase 2
}

National Cancer Institute

\section{Source}

National Cancer Institute. Abelson Tyrosine-Protein Kinase 2. NCI Thesaurus. Code C18533.

Abelson tyrosine-protein kinase $2(1182 \mathrm{aa}, \sim 128 \mathrm{kDa})$ is encoded by the human ABL2 gene. This protein plays a role in cell motility, apoptosis, cell adhesion, receptor endocytosis, autophagy, tyrosine phosphorylation and signal transduction. 